\title{
Law and polity: Some philosophical preliminaries
}

\author{
George Letsas*
}

There are many possible connections between law and polity, some of which are trivial and some which are philosophically contested. The article distinguishes different ways in which there might be a necessary connection between law and polity and offers an account of the concept of polity. In its most abstract sense, a polity can be understood as a community of people, which has a governance structure that members identify with, and which is governed by extensive demands of social justice. The article then moves on to discuss the strongest sense in which there might be a necessary normative connection between law and polity: the idea that the legitimacy of law depends on the existence of a genuine polity, one that possesses certain morally valuable characteristics. It argues that such a strong connection between law and polity faces a challenge: it is either underinclusive, failing to capture much of contemporary international law, or stretches the notion of a polity at breaking point.

\section{Law and other concepts}

Is there a necessary connection between law and polity? There are, no doubt, many possible connections, some of which are trivial and some which are philosophically

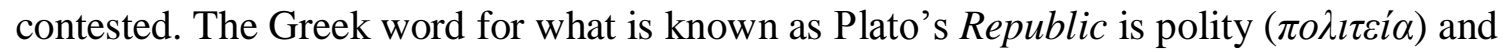

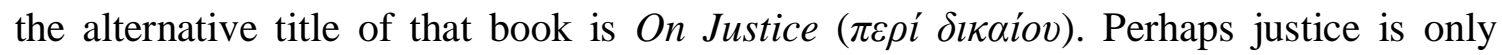
possible within a polity. Or perhaps the aim of a polity is to do justice through law. As elsewhere in philosophy, one needs to begin by analyzing the concept of polity and then making clear which of the many connections between law and polity one has in mind.

I propose to begin by reflecting on a more familiar debate in jurisprudence, that about the relation between law and morality (or justice). This is no doubt a detour, but I hope we can learn something more general about what it is for the law to relate to anything, which we can then use to tackle questions about the relation between law and polity.

The relation between law and morality has for centuries been used as marking the jurisprudential divide between legal positivism and its opponents. In the last 60 years the debate has been greatly advanced by introducing many nuances and qualifications to the question of whether law is embedded in morality. H. L. A. Hart's work was here pivotal. 
In the Concept of Law, ${ }^{1}$ Hart acknowledged the two senses in which the term "morality" can be used: descriptive ("conventional morality") and normative ("critical morality"). The former refers to the set of moral ideas that members of a particular society hold; the latter refers to the moral rights and duties we owe one another in an ideal sense, whether or not the practices of any existing society actually live up to them. The menu of options for the putative connection between law and morality includes the following propositions:

(i) Law is influenced by both conventional and critical morality.

(ii) Law shapes conventional morality.

(iii) Law promises or claims to be moral (in the critical sense).

(iv) Law must secure certain individual moral entitlements (in the critical sense) in order for human societies to survive.

(v) The validity of law depends on conformity with certain demands of critical morality.

Hart was right that some of these propositions are relatively uncontroversial. Take the first two. Some laws, such as obscenity laws against the display of public nudity, clearly reflect the conventional morality of a society. Equally, however, laws often reflect ideas of critical morality that need not be conventionally accepted within a society, such as the legalization of same-sex marriage. It is not uncommon for legislators to pass laws grounded on ideas of justice that are not widely accepted within their society. Such laws may in turn have a causal effect on the conventional morality of a society, gradually leading it to accept that same-sex couples have a moral right to marry.

But as we move down the menu, things become more controversial. Take proposition (iii). Some legal philosophers have argued that law necessarily promises justice. ${ }^{2}$ Others are skeptical that law is the kind of entity that can be said to make claims of any sort. ${ }^{3}$ Hart himself defended the connection between law and morality expressed in proposition (iv), which he labeled the "minimum content of natural law." But later positivists were not at all impressed with the argument that human societies would not survive but for the existence of laws protecting bodily integrity, property, and contracts. ${ }^{4}$ Instead, contemporary legal positivists focused their intellectual energy on proposition (v), the rejection of which they took to be the essence of legal positivism. ${ }^{5}$ Meanwhile, natural

\footnotetext{
* Professor of the Philosophy of Law, University College London. I would like to thank the participants in the Law and Polity workshop at the University of Edinburgh for their very helpful comments and criticisms. I would also like to thank the anonymous reviewers of the journal for helping me to identify (some of the) mistakes in the approach taken in this piece and to sharpen its focus.

${ }^{1}$ H. L. A. HART, THE CONCEPT OF LAW (3d ed., 2012).

2 Jeremy Waldron, Does Law Promise Justice?, 17(3) GA. S. U. L. Rev.759 (2001).

${ }^{3}$ See RonAld DwORKin, Justice in Robes 199ff. (2006).

${ }^{4}$ See Leslie Green, The Morality in Law, in ReAding HLA HaRT's “The ConcePt of LAw” 177 (Luis d'Almeida, James Edwards, \& Andrea Dolcetti eds., 2013).

${ }_{5}^{5}$ See John Gardner, Legal Positivism: 51/2 Myths, 46 AM. J. JuRISPRUDENCE 199 (2001).
} 
lawyers like John Finnis ${ }^{6}$ asserted a different type of connection between law and morality (or justice), without disputing positivists' rejection of (v):

vi. Law is a necessary means by which to effect justice and promote the common good (in the critical sense)

And the most prominent anti-positivist, Ronald Dworkin, ${ }^{7}$ went as far as disputing the very idea that law is separate from critical morality, challenging the "two-systems" view:

vii. Law is a domain of political morality (in the critical sense).

The above seven propositions form a very rough list but one which serves to illustrate the richness of the philosophical landscape and some of the main possibilities when we ask what law's relation to $\mathrm{X}$ or $\mathrm{Y}$ is. We should emphasize the point that what differentiates between the above propositions is not only the sense in which the term "morality" is used (descriptive vs. normative) but also the nature of the relation that they postulate between law and morality. Propositions (i), (ii), and (iv) postulate a connection that is based-at least in part—on empirical assumptions about the causal effects of law as an institutional practice. Propositions (iii) and (v) by contrast purport to capture conceptual truths about law, which cannot be falsified by reference to some empirical fact. Finally, propositions (vi) and (vii) are based on normative assumptions about critical morality, the values that it comprises, and how they pertain to law.

In what follows I shall bracket questions to do with causal connections between law and polity. Such connections no doubt exist, but either they are trivial or they require sophisticated sociological research. Insofar as a polity has a legal system, the norms of that system will be influenced by the character of that polity and the values of its people. And some types of law (e.g. the constitution of a newly formed state) may figure among the causes that lead to the birth of polity. But how exactly this takes place and to what effect is not something to which legal philosophy can provide answers. That is not to say that such questions are not significant. For instance, the social, political, and economic links between the founding of the state of the USA, following the Declaration of Independence, and the birth of a new nation, are fascinating and have exerted a powerful cultural influence. But the issue of what truly counts as polity is logically prior to any historical account. So I shall instead focus on possible conceptual and normative connections between law and polity. Just like morality, a polity can be understood in either a descriptive 
or a normative sense. In its normative sense, it refers to a political community which possesses certain characteristics that-from an idealized critical standpoint-make it worthy of respect and vest it with certain moral powers. Do polities, thus understood, bear any necessary connection to law?

\section{The elements of polity}

An analysis of the concept of polity is bound to be philosophically contentious. So as not to beg any questions, we should seek to analyze polity as abstractly as possible, and I propose to begin by highlighting a few conceptual elements. Competing conceptions of polity will unpack these elements differently, but they should all share them.

The first is the idea of a community, understood as a group of people who have special ties of some kind with one another. What those special ties are can be left open for now. They might possess either an internal or an external dimension, or both. The former refers to a set of positive attitudes and dispositions that members of a group have toward one another, of the kind typically exhibited among compatriots or family members. External ties by contrast refer to events or conditions (such as moving to a new neighborhood) that affect the interests of a number of people and make for a lasting interaction between them. Historically the internal dimension of a political community has been closely linked with nationality. Here is J. S. Mill:

A portion of mankind may be said to constitute a Nationality, if they are united among themselves by common sympathies, which do not exist between them and any others-which make them cooperate with each other more willingly than with other people, desire to be under the same government, and desire that it should be government by themselves, or a portion of themselves, exclusively. This feeling of nationality may have been generated by various causes. Sometimes it is the effect of identity or race and descent. Community of language, community of religion, greatly contribute to it. Geographical limits are one of its causes. But the strongest of all is identity of political antecedents; the possession of national history, and consequent community of recollections; collective pride and humiliation, pleasure and regret, connected with the same incidents in the past. None of these circumstances, however, are necessarily sufficient by themselves. ${ }^{8}$

We must also allow that the external dimension may be causally connected to the internal one. Having to spend one's childhood as part of an extended family or a school

\footnotetext{
8 J. S. Mill, Considerations on Representative Government, in John StUART Mill: COlleCted Works 546 (J. M. Robson ed., vol. 19, 1977), as quoted by John RaWLs, THE LAW OF PEOPLES 23 (1999).
} 
usually cultivates attitudes that make one feel part of a community. But the two dimensions are logically distinct. Moving to a new school or a new job makes one part of a community, even in the absence of any positive attitudes or dispositions toward one's classmates or colleagues. When universities refer to their "student community," they need not presuppose that there are common sympathies among the entire student population. The idea is that the student population constitutes a community by virtue of being part of an institution that affects an important interest of theirs (education), in a systematic way. Being part of that community may or may not lead one to have positive attitudes toward other students or alumni. How far a community can sustain itself when most or all its members show apathy or hostility toward one another is a difficult question. Nor is it clear what level of external interaction is required before we can speak of a community. Twitter users, for instance, are not thought of as a community, at least not in the same way as coworkers and classmates, despite the immediacy of the interaction.

The second element of a polity that seems to me crucial relates to the concept of a political organization, understood as a set of institutional practices through which members of a community govern their common affairs. The presence of a governance structure is necessary in order to distinguish polities from informal communities, such as an extended family or a neighborhood. A governance structure typically encompasses rules setting up executive or legislative bodies and procedures, and allocating decisionmaking powers between them.

Moreover, political institutions must, in the appropriate sense, belong to the people whose lives it governs. There must be some degree of identification and control on the part of the governed. Prisons, for instance, have governance structures, but they are not political organizations. Call this the element of belonging. It suggests that polities have by nature a democratic orientation in that they are incompatible with its members having no say over how political institutions exercise their power. That is not to say that people cannot identify with a monarch whose claim to power rests on a divine right rule a particular nation, as it has been historically the case. Rather, it is that identification through-even rudimentary - forms of democratic governance better captures the essence of polity as compared to, say, an autocracy.

These three elements (community, governance structure, and belonging), abstract as they are, are necessary, but not sufficient, to distinguish polities from mere associations that have an institutional dimension (like a sports club). Fans of a football club are united by special ties of some kind, share common experiences and memories, and govern their football-related activities in an organized manner. But they are hardly a polity. It seems to me that we need to add a fourth, and perhaps more contested, element. Polities are 
distinctive in virtue of the social responsibilities that pertain to them: they are primarily responsible to do justice, through their institutions, with respect to fundamental aspects of their members' well-being. That's not to say that organizations such as FIFA (Fédération Internationale de Football Association) or the International Chess Federation do not have justice-based responsibilities toward their members. What distinguishes polities is that their governance structures have a systematic impact on a comprehensive set of important individual interests (income, housing, health, education, etc.) and, by virtue of that impact, they become a primary agent of social justice: they are responsible for the just distribution of the opportunities, burdens, and benefits that relate to those interests and that fall within their control. A leaseholders' association has a duty to treat its members fairly, but it has little, if any, responsibility for matters of social justice. Call this element responsibility for social justice.

It might be tempting here to link this fourth element to statehood in the following way. States use coercion against people within a particular territory and, by virtue of that power, they can have an impact on people's fundamental interests, triggering responsibilities of social justice. We should, however, resist that temptation. As the concept of statehood is no less contentious than that of polity, using the former to illuminate the latter might add little to our understanding. ${ }^{9}$ Moreover, though the notion of statehood overlaps with that of a polity, the two are clearly not co-extensive. A polity may be smaller (e.g. the Catalans or the Welsh) or larger (e.g. Europeans) than that of a single state. Protectorates had governance structures and legal personality under international law but they hardly qualified as a polity. It is of course true that with the rise of independent nation states, the attributes of a polity began to co-relate with statehood. Throughout the twentieth century states have engaged in various forms of nation-building, and in instilling - through the institutional means of education or propaganda — a sense of group identity on its citizens. They are also nowadays the primary agents responsible for social justice. This co-relation also paved the way for the familiar ideal of popular sovereignty, namely, that each state should comprise a single and self-governing political community. Within that ideal, law is seen as the expression of a true polity: it is made by institutions (legislatures or courts) that represent the members of that community.

Yet we should resist the suggestion that the sources of law must, as a matter of conceptual necessity, emanate from state institutions of a self-governing political

\footnotetext{
9 The same goes for the element of territory. States extend over territory and, in that sense, territory is a necessary element of statehood. But space (and time) are typically proxies for another factor that bears normative significance. Polities necessarily extend spatio-temporally, but it is not an essential characteristic of them. And perhaps, unlike with statehood, the same territory may belong to more than one polity.
} 
community. I have argued elsewhere ${ }^{10}$ that there is no necessary connection between the sources of law on one hand and state institutions on the other. This is no less true of legal positivism, whose methodology seeks to be morally neutral. It is theoretically conceivable within a positivist framework that my grandmother, or Apple, could enact valid law if state courts were to accept and practice criteria of legal validity that give them this power. For legal positivists, it is not who makes the law that matters but how the law becomes valid (i.e. through social facts to do with the practices of officials). The emergence of transnational law - or whatever we wish to call legal standards whose content is not made or authorized by state institutions - is no doubt an interesting development, but that one does not, by itself, undermine the philosophical cogency of legal positivism.

In order to test whether there is a necessary connection between law and polity, understood as having the four elements above (community, governance structure, belonging, and responsibility for social justice), we must instead turn to theories that advocate a strong normative link between the two, under a moralized conception.

\section{Law beyond polity?}

Perhaps the strongest normative link between law and polity is to be found in the work of Ronald Dworkin. Most commentators focus on Dworkin's views on judicial enforcement and his claim that the moral value of integrity pertains to how judges ought to decide cases. But Dworkin's argument begins with what he calls the existence of a true political community. ${ }^{11} \mathrm{He}$ defines a true political community as having four existence conditions: first, a relationship between members of a group that is special and does not hold toward individuals outside it. Second, personal relations between members of the group that are "established directly from each member to each other." Third, reciprocity of concern for the well-being of other members of the group; and fourth, an attitude of equal concern among all its members. ${ }^{12}$

Dworkin moves on to argue that true political communities create obligations for its members in a fashion similar to associations. A subset of these associative obligations flows from the community's past political decisions and relates to rights and duties that can be collectively enforced through its institutions. Dworkin calls the value that governs

\footnotetext{
10 See George Letsas, Harmonic Law: The Case Against Pluralism, in PhilosophicAL Foundations of EuROPEAN UNION LAW 77 (Julie Dickson \& Pavlos Eleftheriadis eds., 2012).

11 See RONALD DWORKIN, LAW's EMPIRE (1986).

12 The requirement of equal concern is that of a genuine and honest egalitarian attitude toward people rather a requirement of actual equal distribution of burdens and benefits and just treatment. It is therefore compatible with some degree of injustice.
} 
how true political communities should enforce their decisions legality. Legality is the answer to a normative question within political morality about the legitimacy of government: which of the obligations that hold among members of a true political community may be collectively enforced?

Dworkin does not use the concept of a polity, nor does he elaborate on the precise connection between state coercion and legality. Yet it is clear that he employs a moralized account of a political community and takes it as the main locus of political values such as justice, equality, and, in his view, integrity. It is against this background that he raises questions about the content of the law and the legitimacy of its enforcement. If polities are best understood as true political communities with governance structures and responsibilities for social justice, then Dworkin's legality is very much tied to them: only polities, we might say, are legality-apt. But what then of EU law, international law, or transnational law? Do they challenge the proposed necessary connection between law and polity?

There are two options to accommodate them under a Dworkinian framework. The first is to fall back on the idea of a state-bound polity and to treat international and transnational law as part of the obligations that citizens of a state, as members of a true polity, have. In his essay on international law, ${ }^{13}$ Dworkin argued that the legitimacy of a state vis-à-vis its own citizens depends on justifying the entire structure of international law. This is a type of monism between domestic and international law: the idea is that a state imposes on its citizens not only its own decisions but the structure of international law of which it forms part. States are responsible for the normative defects of international relations insofar as they bear on the state's ability to act legitimately vis-à-vis its own citizens. As a result, states acquire positive moral duties to respect international law in order to improve their internal legitimacy. Dworkin then sees compliance with suitable rules that have become salient in international law as a demand domestic justice places upon states, even if they have not consented to these rules through a treaty.

The second option is what we might call polity proliferation. Whenever there are good moral reasons to assert a legal obligation, say to review decisions of the Security Council for lack of due process ${ }^{14}$ or to hold states to account for extra-territorial violations of human rights, we should postulate the existence of a true polity. EU nationals should be counted as members of the same polity for the purposes of enforcing EU law and Britons should be counted as members of the same polity with individuals in Iraq or Afghanistan, whose human rights are violated by UK armed forces. The logical end of this line of

\footnotetext{
${ }^{13}$ Ronald Dworkin, A New Philosophy for International Law, 41(1) PHIL. \& PUB. AfF. (2013).

${ }^{14}$ See European Commission and Others v. Kadi, Judgment, Case C-584/10 P, Case C-593/10 P, Case C-595/10 P, ILEC 031 (CJEU 2013), July 18, 2013, European Court of Justice (Grand Chamber).
} 
thought is to assert that the individuals, whose rights are protected by international human rights law, are all members of the same moral community, namely, humanity. ${ }^{15}$

I am skeptical that either of these attempts to forge a necessary connection between law and polity will work. Many hurdles need to be overcome. Take the first option. It seems to me a mistake to treat all the moral obligations states in international law as a means by which to boost their internal legitimacy vis-à-vis their own citizens. Some obligations (like signing up to and complying with human rights treaties) can be said to be of this kind and they take up a sizeable part of contemporary international law. But states do many other things in international law: they collaborate through treaties in order to pursue joint projects in areas that do not bear on their internal legitimacy. Consider the example of a bilateral treaty that facilitates cross-border adoption of children. This issue hardly relates to any of the moral defects of the Westphalian system of international politics that, in Dworkin's view, tarnish the internal legitimacy of state. Such a treaty does, however, amount to political action that might give rise to justiciable legal rights and duties not only for states but also for prospective adoptive parents and adoption agencies. ${ }^{16}$ Moral principles to do with family life and protecting adoptive parents' and children's expectations will then need to guide the judge when shaping the normative content of these rights and duties, in the way Dworkin suggests. None of this, however, seems to have much to do with the moral defects of contemporary international politics.

Nor is there any philosophical payoff to engage in polity-proliferation, as the second option suggests. Take international human rights law. It seems to me that to say that all human beings belong to the same polity, that of humanity or the moral community, is effectively to deny a necessary connection between legality and polity. It is to use the notion of polity in order to make a point that can be made without it, namely, that there are certain grave forms of ill treatment that are universally wrong and that should be of everyone's concern and responsibility not only morally but also within the realm of international law. Nor do we want to say-I think - that the extent to which EU law obligates depends entirely on whether EU citizens can be said to be members of the same demos or polity, exhibiting the characteristics of a true community. Having a legally enforced common market within the EU is a political project that triggers moral requirements of fairness, fair play, protecting expectations, and so on. These moral requirements persist, and ground judicially enforceable rights, regardless of whether special and personal ties hold between the British, the Greeks, and the French-at least the kind of strong ties that Dworkin thinks are necessary for the existence of a true 
community. The British people may exhibit no attitudes of identification toward the European Union after the Brexit referendum, but the United Kingdom still has legal obligations toward the EU, not least in relation to rights of EU citizens (including those of UK nationals living in another EU country). It is possible that failure to create a European demos - understood as attitudes of identification between nations - may make the project of European integration unsustainable. But it does not, in the meantime, make the workings of EU institutions legality-inapt.

Dworkin's emphasis on a polity-based conception of legality is of course no surprise for a theory developed in the USA in the second part of the twentieth century. But the deeper insight of Dworkin's theory seems to me to be what Mark Greenberg calls the "moral impact view"17: political action has a normative impact on people's moral rights, duties, liabilities, and so on. Legality marks out a subdomain of that impact, those rights and duties that are institutionally enforceable. And globalization has shown that the normative effects of political action are wider than the moral obligations members of a polity have toward one another. There is international politics, transnational politics, the politics of multinational corporations, international organizations, and so forth. When courts or other actors ponder over the extent to which these politics result in legally enforceable rights, they are seeking to assess the moral impact of such action. They are carving up conceptual space for law as a domain of the morality of international relations. We could, of course, resist the temptation to occupy this conceptual space, label it as mere 'politics', and hold on to the necessary connection between law and polity. But I see no philosophical motivation for this resistance and many practical benefits if we let go of it. Globalization and transnational politics will still take place and treating them as legalityapt is surely a better strategy for assessing and mitigating its moral arbitrariness. The case for this kind of disembedding law from polity is plausible, both conceptually and morally. 
